MEDEIROS, João Maria Pegado de. A aplicação dos princípios em Dworkin. Revista Eletrônica Direito e Política, Programa de Pós-Graduação Stricto Sensu em Ciência Jurídica da UNIVALI, Itajaí, v.16, n.3, 30 quadrimestre de 2021. Disponível em: www.univali.br/direitoepolitica - ISSN 1980-7791.

\title{
A APLICAÇÃO DOS PRINCÍPIOS EM DWORKIN
}

THE APPLICATION OF THE PRINCIPLES IN DWORKIN

João Maria Pegado de Medeiros'

\section{RESUMO}

O objetivo deste artigo é examinar a teoria dos princípios desenvolvida por Ronald Dworkin em seu livro "Levando os direitos a sério", cuja obra oferece duras críticas ao positivismo jurídico, especialmente ao de Hart. O conteúdo deste trabalho não pretende ser simplesmente analítico, mas terá como fim uma análise crítica em relação à concepção de Dworkin, de modo a fazer uso de alguns conceitos importantes trazidos pelo autor, porém não simplesmente adequando a sua teoria à experiência constitucional brasileira.

Palavras-chave: princípios, direitos fundamentais, direito constitucional.

\section{ABSTRACT}

The purpose of this article is to examine the theory of principles developed by Ronald Dworkin in his book "Taking rights seriously", whose work offers harsh criticisms of legal positivism, especially Hart's theory. The content of this work is not intended to be merely analytical, but will have as its purpose a critical analysis of Dworkin's conception, in order to make use of some important concepts brought by the author, but not simply by adapting his theory to the Brazilian constitutional experience.

Keywords: principles, fundamental rights, constitutional law.

\section{INTRODUÇÃO}

Os princípios jurídicos são mencionados nas decisões judiciais, nos artigos acadêmicos, nas argumentações jurídicas, nos manuais de direito, ora como

1 Mestrando em direito pela Universidade Federal da Bahia, Salvador, Bahia, jmpegadomedeiro@gmail.com. 
MEDEIROS, João Maria Pegado de. A aplicação dos princípios em Dworkin. Revista Eletrônica Direito e Política, Programa de Pós-Graduação Stricto Sensu em Ciência Jurídica da UNIVALI, Itajaí, v.16, n.3, 30 quadrimestre de 2021. Disponível em: www.univali.br/direitoepolitica - ISSN 1980-7791.

aspecto fundante do direito, ora como padrões a serem utilizados pelos aplicadores do direito. Dworkin, ao tratar de princípios, assim coloca:

Uma vez que tenhamos identificado os princípios jurídicos como tipos particulares de padrões, diferentes das regras jurídicas, subitamente nos damos conta de que estão à nossa volta. Os professores de direito os ensinam, os livros de direito os citam e os historiadores do direito os celebram².

Mas o quê são os princípios jurídicos? Onde são encontrados? Como eles operam? Como se relacionam entre si e com demais padrões? Eles somente passam a existir com o direito positivo ou antecedem a ele, possuindo uma existência autônoma? Eles estão inseridos no direito ou são padrões extrajurídicos?

Tais questionamentos atingem qualquer operador do direito: advogados, juízes, doutrinadores. Este artigo, longe da pretensão de exaurir o tema, analisará o conceito de princípio jurídico utilizado pelo autor Ronald Dworkin e, ainda que provisoriamente, se posicionar criticamente em relação à teoria do autor ${ }^{3}$.

\section{A APLICAÇÃo DOS PRINCÍPIOS EM DWORKIN}

\footnotetext{
2 DWORKIN, Ronald. Levando os diretos a sério. $3^{a}$ ed. Tradução de Nelson Boeira. São Paulo: Martins Fontes, 2017, p. 46.

3 O que se busca aqui, ainda que inicial e provisoriamente, dada à complexidade e amplitude do tema, é uma aproximação crítica sobre a visão do autor em relação aos princípios jurídicos. Sendo assim, busca-se evitar uma atitude simplesmente reverencial ou uma tentativa de adaptar a teoria do autor à realidade brasileira, tal como critica Daniel Bonilla sobre a produção latino-americana relacionada às obras de autores anglo-saxões: "En esta medida, los textos de teoria jurídica se presentan como uma sumatoria de interpretaciones exegéticas y glosas explicativas que permitem que las nuevas geraciones de teóricos tengan acceso y conozcan el canon. Así, no es sorprendente encontrar que los anaqueles de teoria jurídica de las bibliotecas de derecho latino-americanas contienen um número importante de libros sobre la teoria de, entre otros, Ronal Dworkin, H. L. A. Hart o Richard Posner. Muchos de estos libros no son diálogos horizontales entre el autor anglosajón y el autor latino-americano. El texto no es uns esfuerzo por pensar juntos un problema teórico e práctico [...]. En outra ocasiones, los textos de teoria jurídica latino-americana buscan aplicar las teorías de los autores metrópoli a sus propias realidades (MALDONADO, Daniel Bonilla et. alii. EI constitucionalismo en el continente americano. $1^{\text {a }}$ ed. Bogotá: Siglo del Hombre Editores, Universidad EAFIT y Universidad de los Andes, 2016, p. 83). No entanto, é preciso colocar que para isso, faz-se necessário uma exposição analítica das ideias de Dworkin, como será visto no decorrer deste artigo.
} 
MEDEIROS, João Maria Pegado de. A aplicação dos princípios em Dworkin. Revista Eletrônica Direito e Política, Programa de Pós-Graduação Stricto Sensu em Ciência Jurídica da UNIVALI, Itajaí, v.16, n.3, 30 quadrimestre de 2021. Disponível em: www.univali.br/direitoepolitica - ISSN 1980-7791.

A teoria dos princípios jurídicos parece não ter sido abordada por dois dos maiores grandes representantes do positivismo jurídico: Kelsen e Hart. O conceito de direito desses autores não se debruça sobre os princípios enquanto espécie de normas jurídicas.

Kelsen apresenta um conceito de validade do direito baseado na denominada norma hipotética fundamental. As normas jurídicas retiram sua validade de uma norma anterior de hierarquia superior até uma norma última, esta pressuposta, a norma hipotética fundamental ${ }^{4}$.

Já o conceito de direito de Hart apresenta a diferenciação entre normas primárias (que ordenam ou dirigem uma conduta) e normas secundárias, parasitárias das primeiras. Nestas últimas, Hart inclui a denominada regra de conhecimento, que seria uma espécie de norma que confere o caráter jurídico a uma norma primária, diferenciando-a, assim de uma norma de conduta extrajurídica ou obrigação moral ${ }^{5}$.

No conceito de direito desenvolvido pelos autores citados, não há um aprofundamento acerca do que seriam os princípios jurídicos e que papel desenvolveria dentro do direito.

Dworkin, em sua obra "Levando os direitos a sério", parte de uma crítica ao positivismo de Hart para afirmar que princípios fazem parte do direito e seriam padrões a serem seguidos pelos juízes nas decisões do que denomina "casos difíceis" (hard cases). Tais casos seriam aqueles em que o juiz não dispõe de uma regra ou precedente que possa ser aplicado no caso concreto, devendo ele decidir com base em outros padrões ${ }^{6}$.

Com relação à aplicação de outros padrões que não regras, ou seja, os princípios, Dworkin aponta que os positivistas não negam a sua existência. Porém,

\footnotetext{
${ }^{4}$ KELSEN, Hans. Teoria pura do direito. $8^{a}$ ed. Tradução de João Baptista Machado. São Paulo: Martins Fontes, 2009, passim.

${ }^{5}$ HART, H. L. A. O conceito de direito. $1^{a}$ ed. Tradução de Antônio de Oliveira Sette-Câmara. São Paulo: Martins Fontes, 2009, passim.

6 DWORKIN, Ronald. Levando os direitos a sério, passim.
} 
MEDEIROS, João Maria Pegado de. A aplicação dos princípios em Dworkin. Revista Eletrônica Direito e Política, Programa de Pós-Graduação Stricto Sensu em Ciência Jurídica da UNIVALI, Itajaí, v.16, n.3, 30 quadrimestre de 2021. Disponível em: www.univali.br/direitoepolitica - ISSN 1980-7791.

para um positivista, os princípios poderiam ser aplicados pelos juízes de forma discricionária, não vinculante. Para os positivistas, a possibilidade de aplicar princípios, ainda que de forma discricionária, decorre do fato de que as regras jurídicas possuiriam limites imprecisos, ou, na denominação de Hart e de Austin, citada por Dworkin, as regras possuiriam uma "textura aberta". Esta "textura aberta" é que possibilitaria aos juízes a aplicação de seu poder discricionário na resolução de casos difíceis.

Na obra citada, que na verdade é composta por uma série de artigos publicados entre 1967 e 1974, Dworkin vai defender uma teoria liberal do direito, ou seja, uma teoria que se pauta na defesa das liberdades individuais perante 0 Estado ou contra a "maioria".

No entanto, alerta ele, que sua teoria não se confundiria com o que chama de teoria dominante do direito, a qual também seria considerada uma teoria liberal. A teoria dominante do direito é dividida por Dworkin em duas partes: (a) uma teoria sobre as condições necessárias e suficientes para a verdade de uma proposição jurídica (positivismo jurídico); e uma teoria de como deve ser o direito (utilitarismo), para a qual o direito e suas instituições deveriam estar a serviço do bem-estar geral e tão somente isso.

O autor irá apresentar uma crítica a essas duas teorias para trazer uma ideia que faz parte da tradição liberal, mas está ausente tanto no positivismo jurídico, como no utilitarismo: a ideia de direitos humanos individuais.

Em Dworkin, os princípios aparecem em sua teoria da decisão judicial, a qual o próprio reputa que deve ser complexa, devendo ser elaborada uma teoria da controvérsia, que estabeleça padrões para que os juízes decidam os casos difíceis e uma teoria da jurisdição, que explique por qual razão e quando os juízes e não outros grupos ou instituições devam tomar decisões exigidas pela teoria da controvérsia.

A teoria normativa de Dworkin se assenta em uma teoria moral e política mais geral, que depende de teorias filosóficas sobre a natureza humana ou objetividade 
MEDEIROS, João Maria Pegado de. A aplicação dos princípios em Dworkin. Revista Eletrônica Direito e Política, Programa de Pós-Graduação Stricto Sensu em Ciência Jurídica da UNIVALI, Itajaí, v.16, n.3, 30 quadrimestre de 2021. Disponível em: www.univali.br/direitoepolitica - ISSN 1980-7791.

moral. Pode-se dizer que sua teoria do direito não é somente jurídica, mas também política.

Em sua crítica, Dworkin considera que a teoria dominante seria falha porque rejeita a ideia de que os indivíduos podem ter direitos anteriores aos direitos criados através da legislação explícita. Aqui parece estar o ponto principal da teoria liberal do autor. Ao contrário da rigidez do positivismo jurídico, o autor reconhece a existência de princípios ou direitos anteriores à legislação ou práticas sociais, aproximando-se de uma concepção quase de direito natural ${ }^{7}$.

A existência de princípios jurídicos é constatada por Dworkin quando os juízes decidem o que denomina de casos difíceis (hard cases). Pode-se incluir, também, na tradição da common law os chamados casos de primeiras impressões (first impressions), que seriam casos colocados ao judiciário com questões nunca analisadas anteriormente.

Como mencionado, esta constatação parte de uma crítica ao positivismo jurídico, sobretudo enquanto considera o direito como um sistema baseado exclusivamente em regras.

Sua crítica começa com o que considera como esqueleto do positivismo jurídico, que poderia assim ser resumido: (a) o direito de uma comunidade é um conjunto de regras com o objetivo de determinar qual comportamento será punido ou coagido pelo poder público. Estas regras, para serem consideradas jurídicas, ou seja, válidas, de modo a diferir de regras espúrias ou diferentes tipos de regras, como as morais, devem passar por um teste fundamental, que o autor denomina de teste de pedigree ; (b) o conjunto dessas regras coexistem com "o direito", de modo que não existindo regra aplicável ao caso apresentado, uma autoridade

\footnotetext{
7 Diz-se "quase", pois como o próprio Dworkin aponta, a ideia de direitos individuais defendidas por ele não pressupõe nenhuma ideia metafísica. Ainda, sobre o tema, na edição constante na bibliografia deste artigo, no capítulo "resposta aos críticos", Dworkin cita que um de seus críticos aponta que seu trabalho segue o que denominou de "direito natural metodológico".

${ }^{8} \mathrm{~A}$ regras de pedigree seriam uma espécie de norma que atestaria quando uma norma poderia ser considerada jurídica ou válida. Considerando os principais autores do positivismo jurídico, Kelsen e Hart, as suas respectivas regras de pedigree seriam a norma hipotética fundamental e a regra de reconhecimento.
} 
MEDEIROS, João Maria Pegado de. A aplicação dos princípios em Dworkin. Revista Eletrônica Direito e Política, Programa de Pós-Graduação Stricto Sensu em Ciência Jurídica da UNIVALI, Itajaí, v.16, n.3, 30 quadrimestre de 2021. Disponível em: www.univali.br/direitoepolitica - ISSN 1980-7791.

pública, como um juiz, deverá decidir além do direito, buscando outro tipo de padrão que oriente na confecção de uma nova regra jurídica ou na complementação de um já existente; (c) quando não há regra jurídica específica a dada situação, significa que o juiz está exercendo seu poder discricionário, criando, assim, uma regra após ao fato.

Dworkin irá argumentar que o positivismo é um modelo de e para um sistema de regras e que sua noção sobre um único teste fundamental para o direito nos forçaria a ignorar os papéis importantes desempenhados pelos padrões que não são regras.

A existência de princípios jurídicos é atestada sobretudo quando se está diante de casos difíceis (hard cases). Para o autor, quando os juristas se debruçam sobre um caso difícil, eles utilizam padrões que não funcionam como regras, mas que operam de forma diferente, tais como princípios, políticas ou outros tipos de padrões.

Dworkin diferencia políticas de princípios. Políticas seriam aqueles padrões que estabelecem um objetivo a ser alcançado, em geral de melhoria em algum aspecto econômico, político ou social da comunidade.

Princípio seria um padrão que deve ser observado, não porque vá promover ou assegurar uma situação política, econômica ou social desejável, mas porque é uma exigência de justiça ou equidade ou alguma outra dimensão da moralidade. Com isso, Dworkin aproxima a teoria do direito a princípios morais ${ }^{9}$.

Dworkin faz a sua famosa distinção entre regras e princípios. A diferença entre tais espécies de normas seria de natureza lógica. As regras seriam aplicáveis à maneira do tudo-ou-nada. Em outras palavras, a regra se aplica ou não ao caso. Já o princípio, não pretende estabelecer condições que tornem sua aplicação

9 DWORKIN, Ronald. Levando os direitos a sério, passim. 
MEDEIROS, João Maria Pegado de. A aplicação dos princípios em Dworkin. Revista Eletrônica Direito e Política, Programa de Pós-Graduação Stricto Sensu em Ciência Jurídica da UNIVALI, Itajaí, v.16, n.3, 30 quadrimestre de 2021. Disponível em: www.univali.br/direitoepolitica - ISSN 1980-7791.

necessária. Ao contrário, enuncia uma razão que conduz o argumento em uma certa direção, mas necessitaria de uma decisão particular.

Desta primeira distinção decorre outra de grande influência na teoria dos princípios. Os princípios possuem uma dimensão que as regras não possuem: de peso ou importância. Quanto dois princípios colidem, aquele que vai resolver o conflito tem de levar em conta a força relativa de cada um.

Para o autor, as regras não possuiriam tal dimensão. Se duas regras entram em conflito, uma delas não pode ser válida. Dworkin afirma, então, que para saber qual delas é válida e qual deve ser deixada de lado, deve-se recorrer a considerações que estão além das próprias regras:

[...] um sistema jurídico pode regular esses conflitos através de outras regras, que dão precedência à regra promulgada pela autoridade de grau superior, à regra promulgada mais recentemente, à regra mais específica ou coisa do gênero. Um sistema jurídico também pode preferir a regra que é sustentada pelos princípios mais importantes ${ }^{10}$.

As distinções entre princípios, políticas e regras bem como a dimensão de peso atribuída aos princípios constitui uma das maiores contribuições de Dworkin para a teoria dos princípios, sendo citado por inúmeros autores, de Alexy, quando menciona a dimensão de peso dos princípios, a Eros Roberto Grau, quando fala sobre a diferença entre políticas e princípios $^{11}$.

A sua divergência com o positivismo jurídico, sobretudo com o positivismo jurídico de Hart, é que essa corrente do pensamento jurídico parece ignorar o papel e a importância dos princípios na aplicação do direito.

\footnotetext{
10 DWORKIN, Ronald. Levando os direitos a sério, p. 43.

${ }^{11} \mathrm{Em}$ sua obra "Teoria dos princípios fundamentais" Alexy cita Dworkin "sobre o conceito e dimensão do peso" dos princípios (ALEXY, Robert. Teoria dos direitos fundamentais. 2a ed. Tradução por Virgílio Afonso Silva. São Paulo: Malheiros Editores, 2011, p. 94). Neste mesmo sentido, vide Eros Roberto Grau, que cita o autor ao discorrer sobre princípios, colocando que estes se diferenciam de políticas pois "a sua observância corresponde a um imperativo de justiça, de honestidade ou de outra dimensão moral" (GRAU, Eros Roberto. A ordem econômica na constituição de 1988. 14ª ed. Malheiros: São Paulo, 2010, p. 156.
} 
MEDEIROS, João Maria Pegado de. A aplicação dos princípios em Dworkin. Revista Eletrônica Direito e Política, Programa de Pós-Graduação Stricto Sensu em Ciência Jurídica da UNIVALI, Itajaí, v.16, n.3, 30 quadrimestre de 2021. Disponível em: www.univali.br/direitoepolitica - ISSN 1980-7791.

Segundo Dworkin, o positivismo jurídico aponta que na ausência de uma regra, o juiz usa de seu poder discricionário para decidir o caso concreto, podendo ou não aplicar determinado princípio. Nessa acepção, os princípios não seriam obrigatórios como as regras e, portanto, não fariam parte do direito. Nos casos difíceis, o juiz iria além do direito, lançando mão de princípios extralegais que teria liberdade para aplicar, se assim o desejar.

Outra grande contribuição para o debate acerca dos princípios trazida por Dworkin é que ele defende que os princípios, assim como as regras, seriam obrigatórios e, portanto, integrantes do direito, devendo ser aplicados pelos juízes.

Para defender este ponto de vista, Dworkin cria uma argumentação a partir da desconstrução das três teorias que compõem o que denominou de esqueleto do positivismo jurídico: (a) a teoria de uma regra de conhecimento fundamental; (b) a teoria do poder discricionário quando o juiz decide casos em que não se apoiam em regras e; (c) a teoria de uma obrigação que afirma a sua inexistência na ausência de uma regra válida até que o juiz, com base no poder discricionário, crie uma nova regra.

Em primeiro lugar, ele vai tratar do que se denomina de poder discricionário do juiz. Para o autor, tal conceito só estaria perfeitamente à vontade em apenas um tipo de contexto: quando alguém é encarregado de tomar decisões estabelecidas por determinada autoridade.

O poder discricionário seria um conceito relativo, que se apresentaria em um sentido fraco e um sentido forte.

No primeiro sentido, o autor cita os casos em que uma autoridade pública deve aplicar padrões que não podem ser aplicados mecanicamente, mas exigem o uso da capacidade de julgar. Outro caso do poder discricionário no sentido fraco, ocorreria quando uma autoridade teria a prerrogativa de tomar uma decisão em última instância. No sentido fraco, a decisão estaria adstrita a padrões anteriormente delimitados, o que não ocorreria no sentido forte. 
MEDEIROS, João Maria Pegado de. A aplicação dos princípios em Dworkin. Revista Eletrônica Direito e Política, Programa de Pós-Graduação Stricto Sensu em Ciência Jurídica da UNIVALI, Itajaí, v.16, n.3, 30 quadrimestre de 2021. Disponível em: www.univali.br/direitoepolitica - ISSN 1980-7791.

Contudo, o autor alerta que, no sentido forte, o poder discricionário não significa que a autoridade esteja livre para decidir o que quiser, sem recorrer a padrões de bom senso ou equidade, apenas que sua decisão não seria controlada por um padrão anteriormente delimitado.

Voltando à teoria do positivismo, quando a doutrina fala em "poder discricionário", Dworkin entende que o termo, pelo menos algumas vezes, é utilizado no sentido forte. Descreve que seria uma tautologia a proposição segundo a qual quando não há regra disponível, deve-se usar o poder discricionário para julgar. Aponta que tal proposição não tem nenhuma relevância para o problema de explicar princípios jurídicos. Para o positivismo a doutrina do poder discricionário seria um insight e não uma tautologia; como se ela tivesse alguma incidência sobre a análise dos princípios.

Para defender, ainda, seu posicionamento de que o poder discricionário é utilizado no sentido forte pelos positivistas, Dworkin cita Hart. Para este autor, ao utilizar o poder discricionário, o juiz não estaria mais vinculado a padrões, mas a padrões que ele tipicamente emprega. Assim, para Hart, os princípios seriam extralegais e o juiz teria liberdade para os aplicar. Em suma, na visão de Dworkin, para os positivistas, os padrões jurídicos que não são regras e são citados pelos juízes não seriam vinculantes.

Dworkin analisa três argumentos utilizados pelos positivistas na teoria do poder discricionário, que, na ausência de regras, o juiz estaria livre para escolher ou não princípios, sendo estes, portanto, não pertencentes ao direito e não vinculantes para os tribunais.

Em um primeiro argumento, o positivismo coloca que os princípios não seriam obrigatórios. Contra tal afirmação, Dworkin argumenta que nos casos difíceis, quando o juiz não se utiliza de um princípio, nem sequer o cogita, seus críticos diriam que seria dever do juiz ponderar entre os princípios envolvidos no caso. Para Dworkin, não bastaria dizer que um tribunal estaria "moralmente" ou "institucionalmente" obrigado a levar em conta princípios. Mesmo assim, alerta o autor, ficaria em aberto a questão do porque este tipo de obrigação - levar em 
MEDEIROS, João Maria Pegado de. A aplicação dos princípios em Dworkin. Revista Eletrônica Direito e Política, Programa de Pós-Graduação Stricto Sensu em Ciência Jurídica da UNIVALI, Itajaí, v.16, n.3, 30 quadrimestre de 2021. Disponível em: www.univali.br/direitoepolitica - ISSN 1980-7791.

conta princípios - é diferente da obrigação que as regras impõem aos juízes e por qual razão se autorizaria dizer que princípios e políticas não são parte do direito, mas meramente padrões extrajurídicos "tipicamente utilizados pelos tribunais".

O segundo argumento é de que, embora alguns princípios sejam obrigatórios, no sentido de que o juiz deve levá-los em consideração, eles não prescrevem um resultado em particular. Quanto a este argumento, no que toca ao resultado, Dworkin coloca que realmente um princípio não prescreve um resultado, mas isto seria apenas diferenciar regras de princípios. Um princípio trabalha de forma diferente de uma regra, na medida em que inclina a decisão em uma direção, embora não conclusiva. E sobrevivem intactos quando não prevalecem. Assim, para Dworkin, esta não parece uma razão para concluir que os juízes possuam poder discricionário, pois um conjunto de princípios pode ditar um resultado. Para o autor, um juiz não possuiria poder discricionário (no sentido forte) ao aplicar princípios obrigatórios, pois teria que confrontá-los e decidir por algum, assim como o faz com as regras.

Um terceiro argumento seria o de que os princípios não podem valer como lei, pois sua autoridade e seu peso são controversos. Aqui Dworkin argumenta que de fato não há como avaliar um princípio como uma lei, quanto à sua validade e seu peso, porém, argumenta-se em favor do princípio e seu peso, tendo em vista o que o autor chama de "amálgama de prática e outros princípios, nos quais as implicações da história legislativa e judiciária aparecem juntamente com apelos às práticas e formas de compreensão partilhadas pela comunidade"12. Dworkin coloca que não existiria um "papel de tornassol", ou seja, um teste para a consistência desse argumento. Neste caso, o autor argumenta que, do mesmo modo, um juiz não possuiria papel de tornassol para decidir qual princípio deveria seguir entre os padrões existentes. Ele não teria poder discricionário, pois deveria chegar a uma compreensão, controversa ou não, a respeito de ordens ou regras que exigem a agir com base nesta compreensão.

12 DWORKIN, Ronald. Levando os direitos a sério, p. 58. 
MEDEIROS, João Maria Pegado de. A aplicação dos princípios em Dworkin. Revista Eletrônica Direito e Política, Programa de Pós-Graduação Stricto Sensu em Ciência Jurídica da UNIVALI, Itajaí, v.16, n.3, 30 quadrimestre de 2021. Disponível em: www.univali.br/direitoepolitica - ISSN 1980-7791.

Assim, combatendo estes três argumentos, Dworkin afasta a segunda premissa positivista, de que os juízes teriam poder discricionário na ausência de regras e, além disso, aponta para a direção de que os princípios fariam parte do direito.

Após apresentar tais argumentos contra a teoria do poder discricionário e a tese de que princípios não fazem parte do direito, Dworkin lança um forte argumento contra esta doutrina e a favor da abordagem que princípios fazem parte do direito. Segundo o próprio autor:

\begin{abstract}
A não ser que pelo menos alguns princípios sejam reconhecidos como obrigatórios pelos juízes e considerados, em seu conjunto, como necessários para chegar a certas decisões, nenhuma regra ou muito poucas regras poderão ser consideradas como obrigatórias para $\operatorname{eles}^{13}$
\end{abstract}

Para sustentar seu argumento, Dworkin cita a possibilidade da mudança de regras de direito costumeiro na Inglaterra e Estados Unidos. Assim coloca que se os tribunais tivessem poder discricionário para modificar regras estabelecidas, não haveria regras obrigatórias e a teoria positivista cairia por terra.

Portanto, os positivistas precisam argumentar que existiriam padrões obrigatórios que estabeleceriam quando um juiz pode e quando não pode revogar ou mudar uma regra estabelecida.

Dworkin aponta que tais padrões seriam os princípios, que funcionariam de duas formas distintas. Em uma primeira, a mudança seria promovida em favor de algum princípio. No entanto, não poderia ser qualquer princípio que poderia justificar a mudança de uma regra, escolhido com base no poder discricionário dos juízes. Existiriam princípios com maior peso que os outros. Na segunda maneira, ao considerar a mudança de uma regra, o juiz deveria levar em conta também princípios, que incluiriam a doutrina da "supremacia do Poder Legislativo" e "doutrina do precedente", as quais apontam em favor do status quo, mas não o impõe. Aqui, mais uma vez, Dworkin aponta que os juízes não teriam liberdade

13 DWORKIN, Ronald. Levando os direitos a sério, p. 59. 
MEDEIROS, João Maria Pegado de. A aplicação dos princípios em Dworkin. Revista Eletrônica Direito e Política, Programa de Pós-Graduação Stricto Sensu em Ciência Jurídica da UNIVALI, Itajaí, v.16, n.3, 30 quadrimestre de 2021. Disponível em: www.univali.br/direitoepolitica - ISSN 1980-7791.

para escolher entre os princípios e as políticas que constituem estas doutrinas, pois se o fossem, nenhuma regra poderia ser considerada obrigatória. Assim, quando o juiz analisa a regra e o princípio que a sustenta, deve verificar se seriam mais importantes que os princípios a favor da mudança.

Por este motivo, para Dworkin, os princípios e políticas seriam padrões obrigatórios para as autoridades de uma comunidade, padrões que regulam suas decisões a propósito de direitos e obrigações jurídicas.

Tendo em vista que os princípios não seriam uma categoria extrajurídica, pois o juiz não deteria o poder discricionário no seu sentido forte, Dworkin aponta que se inclinarmos para a ideia de que princípios integram o direito, seria necessário abandonar a teoria do poder discricionário, pelo menos quanto ao seu sentido forte.

Também seria necessário abandonar ou modificar a doutrina de que o direito pode ser identificado através de testes do tipo especificado em uma regra suprema (teste de pedigree). Para tanto, Dworkin se vale da teoria de Hart para verificar se seria possível submeter os princípios a um teste do tipo especificado naquela regra.

Para Hart, a maioria das normas são válidas porque alguma instituição competente às promulgou. No entanto, a origem dos princípios jurídicos não condiz com tal característica, pois não se encontram na decisão particular de um poder legislativo ou tribunal, "mas na compreensão do que é apropriado, desenvolvida pelos membros da profissão e pelo público ao longo do tempo"14.

Se poderia sustentar que um princípio de direito assim o seria por ser citado em uma decisão ou estar presente na legislação. No entanto, não seria possível precisar o quanto de apoio institucional seria necessário para designar um princípio como princípio de direito. Para Dworkin, a forma como se argumenta com princípios não tornaria possível "aglutiná-los todos em uma única 'regra', por mais complexa que fosse. Mesmo se pudéssemos fazê-lo, o resultado teria pouca

\footnotetext{
${ }^{14}$ DWORKIN, Ronald. Levando os direitos a sério, p. 64.
} 
MEDEIROS, João Maria Pegado de. A aplicação dos princípios em Dworkin. Revista Eletrônica Direito e Política, Programa de Pós-Graduação Stricto Sensu em Ciência Jurídica da UNIVALI, Itajaí, v.16, n.3, 30 quadrimestre de 2021. Disponível em: www.univali.br/direitoepolitica - ISSN 1980-7791.

relação com a imagem de uma regra de reconhecimento, tal como concebida por Hart $^{\prime 15}$.

Além disso, a aguda distinção entre aceitação e validade de Hart não se sustenta em relação aos princípios. Quando se fala que determinada decisão utilizou um princípio ou determinada legislação assim o fez, se estaria falando tanto de aceitação quanto de validade.

Dworkin aponta que os princípios se apoiam mutuamente, não apontando para um princípio que dependeria unicamente da aceitação. Assim, mesmo que presente em legislação ou decisões, os princípios não teriam uma conexão suficientemente direta com uma regra suprema de reconhecimento.

O autor analisa também a questão do costume no positivismo jurídico e especialmente na doutrina de Hart. Neste ponto, assim coloca:

Na verdade, o tratamento dado por Hart ao costume equivale a uma confissão de que existem algumas regras de direito que não são obrigatórias pelo fato de terem sua validade estabelecida de acordo com os padrões de uma regra suprema - mas que são obrigatórias tal como a regra suprema porque são aceitas como obrigatórias pela comunidade. Isso reduz a fragmentos a elegante arquitetura piramidal que admiramos na teoria de Hart: não podemos mais afirmar que apenas a regra suprema é obrigatória em razão da aceitação e que todas as demais regras são válidas nos termos da regra suprema"16.

Assim, se os princípios e políticas fossem aceitos como direito e, portanto, padrões que os juízes seguem, eles retirariam sua força, pelo menos em parte, da própria autoridade dos princípios e das políticas, e não de uma regra suprema de reconhecimento.

Uma última pergunta é feita por Dworkin: seria possível considerar os princípios como regras de reconhecimento? A resposta é negativa, dada à própria natureza

\footnotetext{
15 DWORKIN, Ronald. Levando os direitos a sério, p. 65.
}

16 DWORKIN, Ronald. Levando os direitos a sério, p. 69. 
MEDEIROS, João Maria Pegado de. A aplicação dos princípios em Dworkin. Revista Eletrônica Direito e Política, Programa de Pós-Graduação Stricto Sensu em Ciência Jurídica da UNIVALI, Itajaí, v.16, n.3, 30 quadrimestre de 2021. Disponível em: www.univali.br/direitoepolitica - ISSN 1980-7791.

e estrutura dos princípios, sendo impossível arrolar todos ou resumi-los em uma única proposição.

Deste modo, Dworkin entende que não se poderia aplicar nenhum teste de pedigree aos princípios, devendo ser abandonada, além da teoria do poder discricionário, a primeira teoria do positivismo.

Para o autor, após abandonar as duas teorias, também se deveria abandonar a teoria da obrigação positivista, pois pautada no poder discricionário do juiz. Em suma, se o poder discricionário do juiz é utilizado em seu sentido fraco, ou mesmo se inexistente em seu sentido forte, existiriam obrigações jurídicas além das regras. Para tanto, o autor aponta que "uma obrigação jurídica existe sempre que as razões que sustentam a existência de tal obrigação, em termos de princípios jurídicos obrigatórios de diferentes tipos, são mais fortes do que as razões contra a existência dela"17.

O autor aponta que muitas questões seriam levantadas por tal definição de obrigação jurídica. Mas coloca que o positivismo não chega a enfrentar os casos difíceis e enigmáticos que nos levam a procurar teorias de direito. Para o autor, o positivismo jurídico, diante de tais casos, apenas nos leva à teoria do poder discricionário que nada diz. Segundo Dworkin, a representação positivista enquanto modelo de regras deve ser abandonada em prol de se construir um modelo mais fiel à complexidade e à sofisticação das práticas jurídicas.

Portanto, pode-se dizer que Dworkin apresenta os princípios como integrantes do direito, sendo eles de observância obrigatória pelos juízes. Isso quer dizer que, no pensamento do autor, mesmo que não existam regras específicas para solucionar determinada contenda, uma das partes tem o direito de ganhar a causa.

Uma vez estabelecida a existência de determinados padrões além das regras, consubstanciados em princípios e políticas, Dworkin vai defender que as decisões

17 DWORKIN, Ronald. Levando os direitos a sério, p. 71. 
MEDEIROS, João Maria Pegado de. A aplicação dos princípios em Dworkin. Revista Eletrônica Direito e Política, Programa de Pós-Graduação Stricto Sensu em Ciência Jurídica da UNIVALI, Itajaí, v.16, n.3, 30 quadrimestre de 2021. Disponível em: www.univali.br/direitoepolitica - ISSN 1980-7791.

judiciais nos casos difíceis devem se pautar em argumentos de princípios e não em argumentos de políticas.

Para defender seu ponto de vista, Dworkin analisa duas objeções no que concerne à originalidade da decisão judicial. Estas objeções são apresentadas em favor do argumento de que a decisão judicial deve ficar adstrita à legislação, não podendo "criar um direito".

A primeira objeção afirma que, pelo menos se estivermos diante de uma democracia, as leis devem ser criadas por representantes legitimamente eleitos e não por juízes que são nomeados a par deste processo democrático. A segunda objeção, coloca que o juiz, ao criar uma lei, estaria criando o direito e o aplicando retroativamente.

Tais objeções são válidas quando se está em face de decisões que se fundamentam em argumentos de políticas ${ }^{18}$. Como argumento, Dworkin aponta que, pelo menos quanto ao processo democrático, seria muito mais válido deixar às autoridades legitimamente eleitas a prerrogativa de estabelecer determinadas políticas de melhoria em algum aspecto econômico, político ou social da comunidade, do que a um juiz que não passou pelo crivo do processo eleitoral, tão pouco que não sofre pressão de grupos de interesses específicos. Com relação à segunda objeção, seria extremamente injusto "sacrificar os direitos de um homem inocente em nome de algum novo dever, criado depois do fato" ${ }^{19}$, bem como "tomar os bens de um indivíduo e dá-los a outro, apenas para melhorar a eficiência econômica global"20.

No entanto, tais objeções não seriam válidas em relação aos argumentos de princípios. Quando um juiz utiliza um argumento de princípio para decidir um caso em que não há uma regra específica, ele não está avaliando se dada decisão irá

18 Conforme mencionado anteriormente, Dworkin diferencia políticas de princípios, apesar de ambos serem direcionados às autoridades. Política seria aquele padrão que estabelece um objetivo a ser alcançado, em geral de melhoria em algum aspecto econômico, político ou social da comunidade. Assim, pode-se dizer que para Dworkin, as políticas seriam direcionadas às autoridades do Poder Executivo, na execução de políticas públicas, e ao Poder Legislativo, na edição de leis que promovam tais políticas.

19 DWORKIN, Ronald. Levando os direitos a sério, p. 133.

20 DWORKIN, Ronald. Levando os direitos a sério, p. 133. 
MEDEIROS, João Maria Pegado de. A aplicação dos princípios em Dworkin. Revista Eletrônica Direito e Política, Programa de Pós-Graduação Stricto Sensu em Ciência Jurídica da UNIVALI, Itajaí, v.16, n.3, 30 quadrimestre de 2021. Disponível em: www.univali.br/direitoepolitica - ISSN 1980-7791.

ao encontro de um aspecto econômico, político ou social de dada comunidade, mas está afirmando a existência de um direito. Neste sentido:

[...] um argumento de princípio estipula alguma vantagem apresentada por quem reivindica o direito que o argumento descreve, uma vantagem cuja natureza torna irrelevantes as sutis discriminações de qualquer argumento de política que a ela se pudesse opor. Assim, um juiz que não é pressionado pela maioria política, que gostaria de ver seus interesses protegidos pelo direito, encontra-se, portanto, em uma melhor posição para avaliar o argumento ${ }^{21}$.

Com relação à objeção da originalidade da decisão judicial, Dworkin coloca que a decisão judicial que julga em favor de determinada parte com base em um argumento de princípio não está criando direito novo. Pode-se dizer que, para o autor, o princípio sempre esteve ali, cabendo ao judiciário apenas o dever de declará-lo.

Portanto, não seria possível aos juízes e tribunais utilizarem argumento de política para decidir os casos difíceis, pois se estaria violando a ideia de uma democracia representativa, bem como violando princípios de justiça e equidade ao infligir determinada desvantagem a alguém em nome de uma maioria. Por outro lado, ao se utilizar argumentos de princípios, juízes e tribunais estariam fazendo valer um direito existente daquele que o reivindica, não criando direito novo. Esta é a visão liberal do direito de Dworkin. Em uma democracia, os direitos são a garantia que o indivíduo detém em face tanto do Estado como de uma maioria.

Estabelecida a existência dos princípios no direito e a necessidade de os juízes se valerem de tais argumentos, ao invés de argumentos de política, como, na teoria de Dworkin os princípios são utilizados?

Um primeiro ponto de que deve ser ressaltado é como Dworkin explica a interação, na decisão judicial, da moralidade pessoal do juiz com o que denomina de moralidade institucional. Assim, o autor nos apresenta a "tese dos direitos", "segundo a qual as decisões judiciais tornam efetivos os direitos políticos

\footnotetext{
21 DWORKIN, Ronald. Levando os direitos a sério, p. 134.
} 
MEDEIROS, João Maria Pegado de. A aplicação dos princípios em Dworkin. Revista Eletrônica Direito e Política, Programa de Pós-Graduação Stricto Sensu em Ciência Jurídica da UNIVALI, Itajaí, v.16, n.3, 30 quadrimestre de 2021. Disponível em: www.univali.br/direitoepolitica - ISSN 1980-7791.

existentes"22. Ainda, segundo o autor, "os direitos políticos são criações tanto da história, quanto da moralidade: aquilo que um indivíduo tem direito, na sociedade civil, depende tanto da prática quanto da justiça de suas instituições políticas". ${ }^{23}$

Portanto, pela teoria não só jurídica de Dworkin, mas também política, ao decidir um caso novo ou difícil, o juiz não utiliza seu ideal de moralidade pessoal, mas o institucional, composto de práticas e ideais políticos já assentados na sociedade.

Além disso, os juízes, como autoridades políticas, estariam sujeitos à doutrina da responsabilidade política. Segundo o autor:

[...] as autoridades políticas devem tomar somente as decisões políticas [não confundir como argumentos de política] que possam justificar no âmbito de uma teoria política que também justifique as outras decisões que eles se propõem a tomar ${ }^{24}$.

A doutrina da responsabilidade política demanda o que Dworkin denomina de "consistência articulada", de modo que a aplicação de um princípio esteja coerente com decisões anteriores e com decisões a serem tomadas em uma situação hipotética que um juiz ou tribunal poderia vir a tomar.

Tal doutrina cria o que se pode chamar de "encargo argumentativo" imposto ao juiz ou tribunal. Este não só deve fundamentar sua decisão individualmente, mas de modo que ela faça sentido em relação às demais práticas políticas da sociedade civil.

Para efetuar está consistência articulada, o autor apresenta o que denomina de "conceito contestado", que seria a ação do juiz ou tribunal ao construir o significado do direito fazendo uma série de questionamentos.

Na visão de Dworkin, o juiz irá trabalhar nos casos difíceis com os conceitos de "intenção" ou "propósito" de uma determinada lei, bem como os princípios nos

\footnotetext{
22 DWORKIN, Ronald. Levando os direitos a sério, p. 136.

23 DWORKIN, Ronald. Levando os direitos a sério, p. 136.

24 DWORKIN, Ronald. Levando os direitos a sério, p. 137.
} 
MEDEIROS, João Maria Pegado de. A aplicação dos princípios em Dworkin. Revista Eletrônica Direito e Política, Programa de Pós-Graduação Stricto Sensu em Ciência Jurídica da UNIVALI, Itajaí, v.16, n.3, 30 quadrimestre de 2021. Disponível em: www.univali.br/direitoepolitica - ISSN 1980-7791.

quais se fundam as regras: "os conceitos de intenção legislativa e os princípios do direito costumeiro são artifícios para a aplicação dessa teoria política geral às questões controversas sobre os direitos jurídicos" 25 .

A teoria de Dworkin encarrega o juiz de construir uma argumentação que toma como base "direitos institucionais". Uma das críticas que se pode fazer ao autor é o grande poder conferido ao juiz na construção do direito no caso concreto, não garantindo uma segurança jurídica às partes. A depender do caso, o juiz poderia decidir qualquer coisa baseado unicamente em argumentações de princípios. Assim, o juiz ao decidir pode não se basear em uma teoria política extraída da comunidade, mas pode fazê-lo apenas em suas próprias convicções de moralidade política.

Esta é uma objeção que o autor procura afastar. Para tanto, coloca que os juízes, ao decidirem, não o devem fazê-lo com base em suas convicções pessoais, mas como base em uma moral política dentro da comunidade ao qual está inserido. Dworkin afirma que "os indivíduos têm um direito à aplicação consistente dos princípios sobre os quais assentam suas instituições"26.

No entanto, Dworkin não responde satisfatoriamente à objeção, pois não apresenta um argumento plausível que obrigaria os juízes decidirem de uma certa maneira. O autor parece confiar em demasia no discernimento dos juízes ao se depararem com casos difíceis, de modo a não aplicar suas próprias convicções políticas.

Outro ponto importante que se deve ressaltar novamente, é que Dworkin defende uma teoria liberal do direito, não só jurídica, mas também política. E não só isso, sua teoria liberal e política se refere, especificamente, ao direito e à Constituição estadunidense. Assim, parece restar evidenciado na seguinte passagem, quando o autor adentra na aplicação de princípios constitucionais:

25 DWORKIN, Ronald. Levando os direitos a sério, p. 165.

26 DWORKIN, Ronald. Levando os direitos a sério, p. 197. 
MEDEIROS, João Maria Pegado de. A aplicação dos princípios em Dworkin. Revista Eletrônica Direito e Política, Programa de Pós-Graduação Stricto Sensu em Ciência Jurídica da UNIVALI, Itajaí, v.16, n.3, 30 quadrimestre de 2021. Disponível em: www.univali.br/direitoepolitica - ISSN 1980-7791.

A teoria constitucional [estadunidense] em que se baseia nosso governo não é uma simples teoria da supremacia das maiorias. A Constituição, e particularmente a Bill of Rights (Declaração de Direitos e Garantias), destina-se a proteger os cidadãos (ou grupos de cidadãos) contra certas decisões que a maioria pode querer tomar, mesmo quando essa maioria age visando o que considera de interesse geral ou comum"27.

Na teoria de Dworkin, os elaboradores da constituição estadunidense pretenderam direitos "morais" dos indivíduos em face da "maioria", o que se pode dizer, contra o próprio Estado. Além disso, a utilização do que o autor denomina de "cláusulas constitucionais vagas", ou o que se pode chamar de tipos abertos, pelos constituintes, seria um apelo aos conceitos que tais cláusulas empregam tal como o de legalidade, de igualdade e da proibição da crueldade ${ }^{28}$.

Assim, as cláusulas constitucionais criariam "conceitos de justiça", tipos abertos que o juiz poderia interpretar e criar uma concepção de modo consistente, a partir de uma moral política dentro da comunidade ao qual está inserido, e não "concepções de justiça", ou seja, as cláusulas constitucionais, ao utilizarem tipos abertos não estariam especificando o que se entende por tal direito. Neste sentido:

Se aqueles que promulgaram as cláusulas gerais tivessem desejado estabelecer concepções particulares, teriam se valido do tipo de linguagem que era convencionalmente usado para isso. Isto é, eles teriam oferecido teorias particulares dos conceitos em questão's.

\footnotetext{
27 DWORKIN, Ronald. Levando os direitos a sério, p. 209.

28 Dworkin aponta que a Constituição norte-americana utiliza termos por vezes mais específicos e outros que denomina de padrões "vagos". Neste sentido vide a seguinte passagem, cuja parte inicial já foi citada anteriormente, mas o trecho integral a seguir esclarece melhor a questão dos padrões "vagos": "A teoria constitucional em que se baseia nosso governo não é uma simples teoria da supremacia das maiorias. A Constituição, e particularmente a Bill of Rights (Declaração de Direitos e Garantias), destina-se a proteger os cidadãos (ou grupos de cidadãos) contra certas decisões que a maioria pode querer tomar, mesmo quando essa maioria age visando o que considera ser o interesse geral ou comum. Algumas dessas restrições constitucionais assumem a forma de regras bastante precisas, com a regra que exige um júri no caso de processos criminais federais ou, talvez, a regra que proíbe o Congresso Nacional de restringir a liberdade de expressão. Mas outras restrições assumem a forma daquilo que frequentemente se chama de padrões 'vagos', como por exemplo o dispositivo que determina que o governo não poderá negar a nenhum indivíduo o processo legal justo ou a igualdade proteção perante a lei (DWORKIN, Ronald. Levando os direitos a sério, $p$ 209.

29 DWORKIN, Ronald. Levando os direitos a sério, p. 214.
} 
MEDEIROS, João Maria Pegado de. A aplicação dos princípios em Dworkin. Revista Eletrônica Direito e Política, Programa de Pós-Graduação Stricto Sensu em Ciência Jurídica da UNIVALI, Itajaí, v.16, n.3, 30 quadrimestre de 2021. Disponível em: www.univali.br/direitoepolitica - ISSN 1980-7791.

Uma vez delimitado que a constituição, por vezes se utiliza de conceitos abertos, ou seja, que não apresentam uma concepção estrita de como devem ser entendidos os direitos que as pessoas têm, o autor se posiciona a favor de um "ativismo judicial", em detrimento de uma "moderação judicial":

O programa do ativismo judicial sustenta que os tribunais devem aceitar a orientação das chamadas cláusulas constitucionais vagas [...]. Devem desenvolver princípios de legalidade, igualdade e assim por diante, revê-los de tempos em tempos à luz do que parece ser a visão moral recente da Suprema Corte, e julgar os atos do Congresso, do Estados Unidos e do presidente de acordo com isso. [...] Ao contrário, o programa da moderação judicial afirma que os tribunais deveriam permitir a manutenção das decisões de outros setores do governo, mesmo quando elas ofendam a própria percepção que os juízes têm dos princípios exigidos pela doutrinas constitucionais amplas, excetuando-se, contudo, os casos em que essas decisões sejam tão ofensivas à moralidade política a ponto de violar as estipulações de qualquer interpretação plausível, ou talvez nos casos em que uma decisão contrária for exigida por um precedente inequívoco $[\ldots]^{30}$.

Assim considerando a concepção de que os direitos constitucionais seriam direitos que um indivíduo teria contra a maioria, seria justificável que a interpretação dos conceitos abertos coubesse, em última instância, ao judiciário e não, exclusivamente ao legislativo.

Contudo, a denominada "teoria da democracia" defende que não caberia a um tribunal conferir interpretação diversa da constituição tal qual foi editada. Argumenta-se que em uma democracia, caberia ao poder legislativo, enquanto representante de uma maioria, decidir qual seria o alcance das normas constitucionais, editando leis que passassem pelo crivo do processo legislativo, e não a um grupo de senhores e senhoras que ficam sentados em uma sala que sequer foram legitimadas pelo voto ${ }^{31}$. Nesta passagem Dworkin resume bem seu

30 DWORKIN, Ronald. Levando os direitos a sério, p. 215.

${ }^{31}$ Neste sentido, ver WALDRON, Jeremy. The Core of the Case Against Judicial Review. In: The Yale Law Journal, (2006). Disponível em: https://digitalcommons.law.yale.edu/ylj/vol115/iss6/3. Consulta em 02 mai. 2020. No texto o autor levanta uma série de argumentos contra a possibilidade de o poder judiciário julgar leis inconstitucionais (judicial review) por violarem direitos individuais 
MEDEIROS, João Maria Pegado de. A aplicação dos princípios em Dworkin. Revista Eletrônica Direito e Política, Programa de Pós-Graduação Stricto Sensu em Ciência Jurídica da UNIVALI, Itajaí, v.16, n.3, 30 quadrimestre de 2021. Disponível em: www.univali.br/direitoepolitica - ISSN 1980-7791.

argumento contra a "teoria da democracia", demonstrando que sua teoria está, de fato, atrelada a uma teoria política específica, uma teoria política liberal estadunidense:

Tal postura [de que caberia ao poder legislativo determinar o alcance da legislação constitucional, cabendo ao judiciário sua aplicação estrita], contudo, como tem sido frequentemente sublinhado, ignora o fato de que as decisões a respeito de direitos contra a maioria não são questões que devam, por razões de equidade, ser deixadas a cargo de uma maioria. O constitucionalismo - a teoria segundo a qual os poderes da maioria devem ser limitados para que se protejam os direitos individuais - pode ser uma teoria política boa ou má, mas foi adotada pelos Estados Unidos, e não parece justo ou coerente permitir que a maioria julgue em causa própria. Dessa forma, os princípios de justiça parecem posicionar-se contra o argumento derivado da democracia, e não a seu favor ${ }^{32}$.

O seguinte trecho resume bem a concepção de Dworkin quanto aos direitos constitucionais e sua aplicação nos "casos difíceis":

Nosso sistema constitucional baseia-se em uma teoria moral específica, a saber, a de que os homens têm direitos morais contra o Estado. As cláusulas difíceis da Bill of Rights, como as cláusulas do processo legal justo e da igual proteção, devem ser entendidas como um apelo a conceitos morais, e não como uma formulação de concepções específicas.

deduzidos do texto constitucional estadunidense. Para o autor, em uma democracia, seria inadequada a possibilidade de o judiciário estabelecer, em última instância, os direitos de uma sociedade: "by privileging voting among a small number of unelected and unaccountable judges, it disenfranchises ordinary citizens and brushes aside cherished principles of representation and political equality in the final of issues about rights". Tradução livre: "privilegiar o voto de um pequeno número de juízes não eleitos e que não respondem a ninguém, priva o cidadão comum do direito de voto e deixa de lado caros princípios de representação e de igualdade política nas questões finais sobre direitos" (Op. cit., p. 1353). A visão do autor é contrária à visão de Dworkin de que os direitos seriam a proteção do indivíduo contra uma maioria. Waldron rechaça o argumento da "tirania de uma maioria", apontando que em alguns casos, alegações deste tipo são encontradas em ambos os lados envolvendo discussões de direitos, como nos casos de defensores da legalização do aborto e defensores de sua proibição. No entanto, assim como Dworkin atribui grande peso aos juízes para resolverem questões de direito, Waldron o faz em relação ao legislativo. O próprio autor reconhece que em questões de injustiça racial, por exemplo, uma maioria pode criar problemas de igualdade em detrimento de uma minoria. Porém, mesmo nestes casos, Waldron é contra a possibilidade de o judiciário intervir e decretar determinada lei discriminatória inconstitucional, cabendo à sociedade revogá-la por meio do poder legislativo. O autor cita, especificamente neste caso, que com relação às declarações de inconstitucionalidade das leis estadunidenses de segregação (Brown e outros casos) nos anos 50 e 60, foi necessária uma forte intervenção legislativa na forma da edição do Civel Rights Act pela legislatura federal para que leis estaduais de segregação fossem revogadas.

32 DWORKIN, Ronald. Levando os direitos a sério, pp. 222 a 223. 
MEDEIROS, João Maria Pegado de. A aplicação dos princípios em Dworkin. Revista Eletrônica Direito e Política, Programa de Pós-Graduação Stricto Sensu em Ciência Jurídica da UNIVALI, Itajaí, v.16, n.3, 30 quadrimestre de 2021. Disponível em: www.univali.br/direitoepolitica - ISSN 1980-7791.

Portanto, um tribunal que assume o ônus de aplicar plenamente tais cláusulas como lei deve ser um tribunal ativista, no sentido de que ele deve estar preparado para formular questões de moralidade política e dar-lhes uma resposta ${ }^{33}$.

Dworkin crítica o que denomina de falsa escolha entre o "ativismo judicial", considerado indevidamente como uma cruzada pela moral, e a "moderação judicial", corrente pela qual o jurista deveria se ater tão somente à norma e deixar ao legislador a escolha pelo alcance dos termos abertos da constituição, sendo esta teoria a representante da defesa da legalidade estrita.

Para o autor, o progresso do direito constitucional dependeria de uma fusão entre direito constitucional e a teoria moral. Longe de trazer ideias metafísicas ou fantasmagóricas, a filosofia seria capaz de trazer para o direito uma teoria de direitos morais contra o Estado.

\section{CONSIDERAÇÕES FINAIS}

A importância do pensamento de Dworkin para teoria dos princípios jurídicos é inegável. Dentre as contribuições que podem ser citadas, há a própria defesa dos princípios como padrões a serem seguidos além das regras.

Por meio de sua crítica ao positivismo, Dworkin traz para o debate jurídico a existência de padrões que, aparentemente, foram relegados pela corrente positivista, que via somente nas regras a expressão da norma jurídica.

Além disso, a distinção entre princípios e regras abriu caminho para toda uma teoria que os diferencia, inclusive para efeitos de aplicação destes padrões nas decisões judiciais. Tais padrões possuem estruturas diferentes. A aplicação das regras se resolve pela subsunção: uma regra é aplicável ou não. O princípio, por outro lado, dado à dimensão de peso, é aplicável por meio da ponderação.

\footnotetext{
33 DWORKIN, Ronald. Levando os direitos a sério, p. 231.
} 
MEDEIROS, João Maria Pegado de. A aplicação dos princípios em Dworkin. Revista Eletrônica Direito e Política, Programa de Pós-Graduação Stricto Sensu em Ciência Jurídica da UNIVALI, Itajaí, v.16, n.3, 30 quadrimestre de 2021. Disponível em: www.univali.br/direitoepolitica - ISSN 1980-7791.

Todavia, a teoria de Dworkin não é convincente o suficiente quando tenta explicar os motivos pelos quais os princípios seriam obrigatórios, tal como as regras.

Kelsen, além de apontar para a necessidade de uma norma válida, por outra imediatamente anterior, entende que o direito é ordem coercitiva, que prescreve uma sanção em caso de descumprimento.

Em sua crítica ao positivismo, Dworkin tenta explicar a obrigatoriedade dos princípios de diversas formas. Apela para um argumento de que quando os juízes não os utilizam, sente-se falta deles. Em outro momento, quando se coloca a objeção de que os princípios não poderiam valer como leis em razão da controvérsia quanto à sua autoridade e peso, aponta que o dever de segui-los decorre de um "amálgama de prática e outros princípios, nos quais as implicações da história legislativa e judiciária aparecem juntamente com apelos às práticas e formas de compreensão partilhadas pela comunidade"34. Com este mesmo argumento, afirma que não se pode aplicar um teste para verificar se um princípio é jurídico ou não, pois ele decorre do desenvolvimento de uma compreensão empreendida por juristas e membros da comunidade do que é apropriado.

O autor também critica a ideia de Hart de que determinados padrões seriam aplicados pelos juízes em razão destes assim entenderem como obrigatórios e por existir uma regra social observável neste sentido. Para o autor, a base para aplicação de princípios estaria vinculada a uma teoria moral e política, que deve ser justificada pelo aplicador do direito ${ }^{35}$.

Um positivista pode explicar a obrigatoriedade de uma regra em razão de sua validade enquanto ordem coercitiva ou regra observada pela comunidade. Dworkin

\footnotetext{
34 DWORKIN, Ronald. Levando os direitos a sério, p. 58.

35 Neste sentido, vide a seguinte passagem: "Se uma teoria deve fornecer uma base para o dever judicial, então os princípios que ela apresenta de maneira ordenada devem tentar justificar as regras estabelecidas. Para isso, é preciso identificar as preocupações e tradições morais da comunidade que, na opinião do jurista que defende tal teoria, sustentam efetivamente essa regra. Esse processo de justificação deve levar o jurista ao exame muito aprofundado da teoria moral e política e bem além do ponto em que é acurado dizer que existe algum 'teste' de 'pedigree' para decidir qual das justificações diferentes de nossas instituições políticas é superior à outra" (DWORKIN, Ronald. Levando os direitos a sério, p. 106.
} 
MEDEIROS, João Maria Pegado de. A aplicação dos princípios em Dworkin. Revista Eletrônica Direito e Política, Programa de Pós-Graduação Stricto Sensu em Ciência Jurídica da UNIVALI, Itajaí, v.16, n.3, 30 quadrimestre de 2021. Disponível em: www.univali.br/direitoepolitica - ISSN 1980-7791.

tenta explicar a obrigatoriedade dos princípios a partir de uma teoria da argumentação, colocando o jurista como responsável por construir conceitos a partir de uma teoria moral e política de dada comunidade. Seu conceito está de acordo com as suas premissas: Dworkin se baseia mais em uma tese de argumentação do que na demonstração de uma proposição válida tal qual é a teoria do positivismo jurídico.

Todavia, isso cria duas questões: uma se refere à segurança jurídica e a outra se refere à existência dos direitos que as pessoas possuem.

É nítida a relação entre segurança jurídica e positivismo jurídico. Aquela é garantida na medida em que determinados princípios são positivados, vinculando o jurista e cabendo ao intérprete, de fato, construir seu significado a partir da realidade social.

Com relação à questão da existência dos direitos, Dworkin defende que estes existem a despeito do direito posto. Segundo o autor, as pessoas possuem direitos morais contra o Estado ou contra a "maioria". A impressão ao ler o autor é que, muito embora tente explicar os direitos como entidades não fantasmagóricas ou metafísicas, ele parece considerar que os direitos sempre existiram.

No entanto, é preciso observar que os direitos são conquistas históricas que ocorreram em determinado momento. Os direitos que as pessoas têm não surgiram simplesmente a partir da razão humana ou qualquer conceito metafísico, mas foram resultados de processos históricos decorrente de revoluções, lutas, correntes filosóficas e uma série de outros acontecimentos que redundaram com a promulgação de declarações e constituições ${ }^{36}$.

\footnotetext{
36 Não se pode deixar de mencionar que existem autores renomados que defendem a ontologia dos direitos, mais precisamente dos direitos humanos, tal como Fábio Konder Comparato. Para este autor, o fundamento dos direitos humanos está localizado no próprio homem, enquanto ser único, dotado de racionalidade, autoconsciência e dignidade (COMPARATO, Fábio Konder. Fundamento dos Direitos Humanos. Disponível em http://www.dhnet.org.br/direitos/anthist/a_pdf/comparato_fundamentos_dh.pdf>. Consulta em 8 dez. 2018). Longe de ser o objetivo deste artigo em encontrar um fundamento para os direitos humanos e os princípios que deles se extraem ou contraditar o citado autor - o que aliás daria uma tese inteira -, vale salientar que o próprio autor reconhece que "a ciência jurídica ainda não logrou
} 
MEDEIROS, João Maria Pegado de. A aplicação dos princípios em Dworkin. Revista Eletrônica Direito e Política, Programa de Pós-Graduação Stricto Sensu em Ciência Jurídica da UNIVALI, Itajaí, v.16, n.3, 30 quadrimestre de 2021. Disponível em: www.univali.br/direitoepolitica - ISSN 1980-7791.

Faz-se, também, uma ressalva à teoria de Dworkin. Em que pese trazer conceitos importantes para uma teoria dos princípios, ela se funda em uma concepção política e constitucional muito específica. Sua teoria, se refere não só a uma teoria liberal do direito, mas a uma teoria liberal do direito baseada na política e constituição estadunidense.

A explicação para obrigatoriedade dos princípios e a forma de aplicação pode se adequar à constituição estadunidense, pautada em tipos mais abertos ou normasprincípio, que, de fato, exigem um encargo argumentativo dos juízes para construir e aplicar tais conceitos no caso concreto.

No entanto, se formos verificar a constituição brasileira, podemos afirmar que esta, mesmo quando veicula princípios (legalidade, igualdade, dignidade etc.) o faz por meio de normas-regras, o que exige uma outra teoria para aplicação dos princípios.

À par de tais críticas, as contribuições da teoria de Dworkin a uma teoria dos princípios é evidente, principalmente no que se refere à dimensão de peso dos princípios e a sua diferenciação de regras. Tais conceitos, de suma importância, podem ser compatibilizados com o positivismo jurídico (apesar de o próprio Dworkin entender o contrário), desde que adicionados a uma teoria de que o texto normativo não se confunde com a norma jurídica ${ }^{37}$.

encontrar uma definição rigorosa de direito humano" ou mesmo de direito (COMPARATO, Fábio Konder. Fundamento dos Direitos Humanos, p. 9). Aliado a isto, mesmo os direitos que hoje se consideram como pertencentes a qualquer ser humano, independentemente a quais leis ele se sujeita, tal como o direito de não ser escravizado ou torturado, um dia foram permitidos em dada sociedade, sendo direito possuir um escravo ou torturar alguém que cometeu um crime. Diante de tais fatos, ainda que seja uma posição provisória, não se vê demérito algum em considerar os direitos como fruto de conquistas e lutas históricas, sujeitos à proibição do retrocesso, dado ao pensamento ético vigente.

37 Sobre texto constitucional e interpretação: "Como a interpretação/aplicação se dá no quadro de uma situação determinada, expõe o enunciado semântico do texto no contexto histórico presente, não no contexto da redação do texto. Assim se opera também, em linhas gerais, a interpretação da Constituição. Compreendemos necessariamente, ao interpretá-la, além dos seus textos, a realidade. A interpretação da Constituição não é exclusivamente do texto da Constituição formal (GRAU, Eros Roberto. A ordem econômica na constituição de 1988, p. 167). Ainda, sobre diferença entre texto e norma, Eros Grau cita José Joaquim Gomes Canotilho, o qual faz referência a F. Muller. 
MEDEIROS, João Maria Pegado de. A aplicação dos princípios em Dworkin. Revista Eletrônica Direito e Política, Programa de Pós-Graduação Stricto Sensu em Ciência Jurídica da UNIVALI, Itajaí, v.16, n.3, 30 quadrimestre de 2021. Disponível em: www.univali.br/direitoepolitica - ISSN 1980-7791.

A norma jurídica, extraída pelo intérprete do texto normativo pode ser tanto um princípio quanto uma regra. Considerando, assim, a estrutura de uma regra, não seria válido, por exemplo, afastá-la utilizando um princípio. Isto em razão de, ao optar por uma regra, o legislador já realizou uma ponderação entre princípios e escolheu um deles, não sendo dado ao intérprete livremente afastar a regra (fruto de uma ponderação de valores), salvo se o princípio que a sustenta entrar em conflito com outro princípio de natureza constitucional, sendo este resolvido pela ponderação.

\section{REFERÊNCIAS DAS FONTES CITADAS}

ALEXY, Robert. Teoria dos direitos fundamentais. $2^{a}$ ed. Tradução por Virgílio Afonso Silva. São Paulo: Malheiros Editores, 2011.

COMPARATO, Fábio Konder. Fundamento dos Direitos Humanos. Disponível em http://www.dhnet.org.br/direitos/anthist/a_pdf/comparato_fundamentos_dh.pdf >. Consulta em 8 dez. 2018.

DWORKIN, Ronald. Levando os diretos a sério. 3a ed. Tradução de Nelson Boeira. São Paulo: Martins Fontes, 2017.

GRAU, Eros Roberto. A ordem econômica na constituição de 1988. $14^{a}$ ed. Malheiros: São Paulo, 2010.

HART, H. L. A. O conceito de direito. $1^{\text {a }}$ ed. Tradução de Antônio de Oliveira Sette-Câmara. São Paulo: Martins Fontes, 2009.

KELSEN, Hans. Teoria pura do direito. $8^{a}$ ed. Tradução de João Baptista Machado. São Paulo: Martins Fontes, 2009.

MALDONADO, Daniel Bonilla et. alii. El constitucionalismo em el continente americano. $1^{\text {a }}$ ed. Bogotá: Siglo del Hombre Editores, Universidad EAFIT y Universidad de los Andes, 2016.

WALDRON, Jeremy. The Core of the Case Against Judicial Review. In: The Yale Law Journal, (2006). Disponível em: https://digitalcommons.law.yale.edu/ylj/vol115/iss6/3. Consulta em 02 mai. 2020. 
MEDEIROS, João Maria Pegado de. A aplicação dos princípios em Dworkin. Revista Eletrônica Direito e Política, Programa de Pós-Graduação Stricto Sensu em Ciência Jurídica da UNIVALI, Itajaí, v.16, n.3, 30 quadrimestre de 2021. Disponível em: www.univali.br/direitoepolitica - ISSN 1980-7791. 